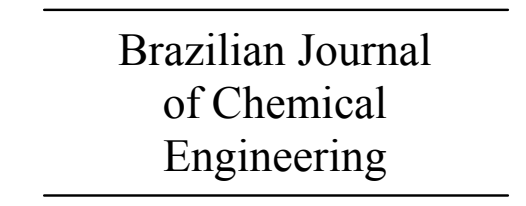

ISSN 0104-6632

Printed in Brazil

www.abeq.org.br/bjche

Vol. 29, No. 04, pp. 741 - 750, October - December, 2012

\title{
DRYING KINETICS, STRUCTURAL CHARACTERISTICS AND VITAMIN C RETENTION OF DEDO-DE-MOÇA PEPPER (Capsicum baccatum) DURING CONVECTIVE AND FREEZE DRYING
}

\author{
A. O. M. $\operatorname{Veras}^{1}$, R. Béttega ${ }^{2}$, F. B. Freire ${ }^{1}$, M. A. S. Barrozo ${ }^{2}$ and J. T. Freire ${ }^{1 *}$ \\ ${ }^{1}$ Drying Center of Pastes, Suspensions and Seeds, Department of Chemical Engineering, \\ Federal University of São Carlos, Rod. Washington Luís Km 235, 13565-905, São Carlos - SP, Brazil. \\ E-mail: freire@ufscar.br \\ ${ }^{2}$ School of Chemical Engineering, Federal University of Uberlândia, 38400-902, Uberlândia - MG, Brazil.
}

(Submitted: February 7, 2012 ; Revised: May 18, 2012 ; Accepted: June 1, 2012)

\begin{abstract}
The main objective of this study was to evaluate the effect of the drying process on the vitamin C levels and physical properties of dedo-de-moça pepper. The drying kinetics and the structural properties were determined as a function of moisture content. Convective drying was compared with freeze-drying in terms of product quality, structural properties, retention of vitamin $\mathrm{C}$ and rehydration characteristics. Empirical and semi-empirical equations were used to describe the drying and rehydration kinetics. Nonlinear analysis applied to results of convective drying, based on curvature measures and bias measures, showed that the only equation that gives good inference results based on least squares estimators is the Overhults equation. The characterization of the rehydration process was done by determining the indexes that take into account the water absorption capacity and solutes losses. The material dried by lyophilization show greater potential to rehydrate.

Keywords: Drying; Lyophilization; Rehydration; Ascorbic acid; Product quality.
\end{abstract}

\section{INTRODUCTION}

Among the 25 species of pepper Capsicum, only 5 are regularly cultivated: $C$. annuum L. var. pendulum (dedo-de-moça pepper), C. annuum L. var. annuum, $C$. chinense Jacq., C. frutescens $\mathrm{L}$. and C. pubescens. The others are mostly considered wild species (Hunziker, 1979).

In order to be competitive, small producers of pepper have to employ efficient seasoning methods to preserve their products during storage. This has to be carefully done especially to maintain the chemical and pharmacological aspects of pepper (Rietjens et al., 2002). A number of factors, including $\mathrm{pH}$, oxygen concentration, moisture content, temperature and metallic acid catalysts (Uddin et al., 2002), influence vitamin $\mathrm{C}$ activity. One of the food industry goals is to preserve the maximum product nutrient content during processing and storage (Duarte et al., 2004), and, according to Gregory (1996), this may be evaluated using ascorbic acid as an index of the nutrient quality.

Conventional drying with hot air is commonly encountered in dehydration (Lisboa et al., 2007; Barrozo et al. 2006). However, an alternative way to remove excess water from food is by lyophilization, which is a drying process based on water sublimation from the material caused by application of low

*To whom correspondence should be addressed 
pressure on frozen material. This technique results in high-quality dehydrated products (Mujumdar, 1987). The low temperatures of lyophilization and the absence of dry air prevent the degradation of thermolabile, biological and pharmaceutical substances (Lombraña and Izkara, 1996). When compared to thermally dried products, food dehydrated by lyophilization usually has more quality, which is related to properties such as low apparent density, high porosity, remarkable aroma and flavor, and excellent rehydration potential.

Several works on Capsicum pepper drying are found in the literature, as shown in Table 1. A closer look at Table 1 reveals that most contributions were on drying of the pepper Capsicum annum L. Even though C. baccatum var. pendulum pepper (dedo-demoça pepper) is popular throughout the world, there are only a few works on the drying of this kind of pepper.

The objective of the present work was to investigate the convective drying of $C$. baccatum var. pendulum (dedo-de-moça pepper) and compare the final product with dehydrated pepper obtained by lyophilization. The effect of the drying process on the nutritional composition and physical properties of dedo-de-moça pepper was analyzed during and after processing. For this purpose, the drying kinetics and the structural properties (true density, apparent density, porosity and shrinkage) were determined as a function of moisture content during drying.

\section{NONLINEARITY MEASURES}

Since the majority of the drying kinetic equations are nonlinear, care should be taken when estimating their parameters from experimental data (Barrozo et al., 1996; Arnosti Jr. et al., 1999). Thus, comparisons of the $\mathrm{R}^{2}$ values and residuals analysis may be insufficient to discriminate between nonlinear regression models like drying kinetics equations (Ribeiro et al., 2005). In some situations, the estimators (especially confidence intervals) may not be appropri- ate (Vieira et al., 2005). Thus, some procedures are available in the literature to validate the statistical properties of the least squares (LS) estimators of nonlinear models. Box (1971) presented a useful formula for estimating the bias in the LS estimators; Bates and Watts (1980) developed new measures of nonlinearity based on the geometric concept of curvature. They separated the nonlinearity of a model into two components: one associated with the curvature of the solution locus, called "intrinsic" nonlinearity (IN), and another associated with the fact that the projections of the parameter lines on the tangent plane to the solution locus are neither straight, parallel, nor equispaced, called the "parameters effect" (PE).

A negligible intrinsic nonlinearity (IN) means a negligible bias in the predicted values of the response. Nonlinearity due to the parameter effect (PE), which depends on the sequence that the parameters appear in the model, is a consequence of the lack of uniformity of the coordinate system in the estimation space. When the nonlinearity is mostly due to the effects of parameters, a reparametrization becomes important. If the parameter-effect (PE) nonlinearity is negligible, the statistical tests of the consistency of the fitted parameters will be valid. The statistical significance of (IN) and (PE) can be assessed by comparing these values with the radius of the confidence region, $100(1-\alpha) \%$, which is equal to: $1 / 2 \sqrt{\mathrm{F}} \cdot \mathrm{F}=\mathrm{F}(\mathrm{p}, \mathrm{n}-\mathrm{p}, \alpha)$ is obtained from a table of the F-distribution.

Details about the development, procedure and equations for determining (IN) and (PE) are found in Bates and Watts (1980).

Box (1971) proposed an equation to evaluate the bias in the estimated LS parameters. The bias expressed as a percentage of the LS estimate is a useful quantity, as an absolute value in excess of $1 \%$ appears to be a good rule of thumb for identification of which parameter, or parameters, are responsible for the nonlinear behavior. Once these parameters are known, a reparametrization can be sought to reduce the nonlinearity.

Table 1: Contributions to Capsicum pepper drying

\begin{tabular}{|l|l|l|}
\hline References & Technique/drier & Pepper \\
\hline Turhan and Turhan (1997) & Convective drier. & C. annum L. \\
Gupta et al. $(2002)$ & Chamber. & Cannum L. \\
Kaymak-Ertekin $(2002)$ & Fluidized bed. & C. annum L. \\
Tunde-Akintunde et al. $(2005)$ & Convective and natural. & C. annum L. \\
Ergüneş and Tarhan (2006) & Natural and Chamber. & C. annum L. \\
Kim et al. $(2006)$ & Chamber. & C. annuum cv. Baklouti. \\
Kooli et al. $(2007)$ & Convective and natural & C. annum L. \\
Vega et al. $(2007)$ & Convective. & C. annum L. \\
Scala and Crapiste $(2008)$ & Crossed flow drier. & \\
\hline
\end{tabular}




\section{MATERIALS AND METHODS}

\section{Materials and Experimental Methodology}

The pepper used in this work was obtained from commercial trading stores of the city of São Carlos (Brazil) and, before being processed; were washed and sliced into flat plates. The experimental setup for convective drying consisted of a blower, a series of electrical resistances to heat the air, a temperature controller and homogenizing plates. Experiments were done at 50,60 e $70{ }^{\circ} \mathrm{C}$ with an air flow velocity of $1.5 \mathrm{~m} . \mathrm{s}^{-1}$. Samples consisted of plates $(1.0 \times 4.0 \mathrm{~cm})$ and were placed peel down onto a screen. Mass variation was measured using steps of $5 \mathrm{~min}$ for the first 30 minutes and then using non-periodic intervals until constant mass was reached. An analytical balance (ADN, HR-200) $\pm 10^{-4} \mathrm{~g}$ was used. The dried mass content was found by assays in a heating chamber $\left(105 \pm 3.0^{\circ} \mathrm{C}\right.$ - 24hours). Figure 1 presents the layout of the experimental unit.

The freeze- drying experiments were performed in a Labconco lyophilizer (model 77535). The samples were frozen with nitrogen $\mathrm{N}_{2}(\mathrm{v})$ for 15 minutes. Drying curves were obtained for samples collected from the lyophilizer at intervals of 30 minutes with the mass measured using an analytical balance.

Ascorbic acid losses due to the drying process were verified. For this comparison the content of vitamin $\mathrm{C}$ was analyzed in fresh fruit, after drying and after rehydration. The method of AOAC (967.21) using a titration of 2.6-dichlorophenolindophenol (DCFI) with slight modifications was applied. The amount of $1.0 \mathrm{~g}$ of sample was homogenized in $50 \mathrm{~mL}$ of $1 \%(\mathrm{w} / \mathrm{v})$ metaphosphoric acid. This solution was filtered and samples of $10 \mathrm{~mL}$ were taken for titration with DCFI. The endpoint of the titration was determined visually and the procedure was conducted in triplicate.

The porosity $(\varepsilon)$ was determined from values of the real density $\left(\rho_{\mathrm{r}}\right)$ and apparent density $\left(\rho_{\text {ap }}\right)$, as given by Equation (1):

$$
\varepsilon=1-\frac{\rho_{\text {ap }}}{\rho_{\mathrm{r}}}
$$

The real density was measured with a helium pycnometer (Quantachrome Instruments) and the apparent density by liquid pycnometry with hexane.

Shrinkage after drying (assumed as onedimensional) was evaluated by means of the sample thickness decrease. Measurements of thickness were done in three different places with a digital paquimeter.

\section{Drying Kinetics Equations}

The drying kinetics of food materials are a complex phenomenon and, for some products, are scarce in the literature. Hence, experimental studies and application of simplified models to represent the drying behavior are still required (Barrozo et al., 2001). A number of empirical and semi-empirical equations have been proposed in the literature (Lewis, 1921; Brooker et al., 1974; Henderson and Henderson, 1968; Page, 1949; Overhults et al. 1973, among others) to describe the drying kinetics of biological materials. Table 2 shows the drying kinetics equations analyzed in the present work.

Lewis (1921) proposed Equation (2) using an analogy with Newton's law of cooling. Equations (3) and (4) are simplifications of the analytical solution of the diffusional model (Brooker et al., 1974; Henderson and Henderson, 1968). The Page (1949) and Overhults et al. (1973) equations originated from empirical modifications of the Lewis equation.

In the equations of Table 2, MR is the dimensionless moisture number (as presented in Equation (7). $\mathrm{M}_{\mathrm{eq}}$ is the equilibrium moisture content; $\mathrm{M}_{0}$ is the initial moisture content; $\mathrm{t}$ is the drying time; $\mathrm{T}$ is the fluid temperature; $\mathrm{A}, \mathrm{B}, \mathrm{C}, \mathrm{d}$ and $\mathrm{K}$ are constants.

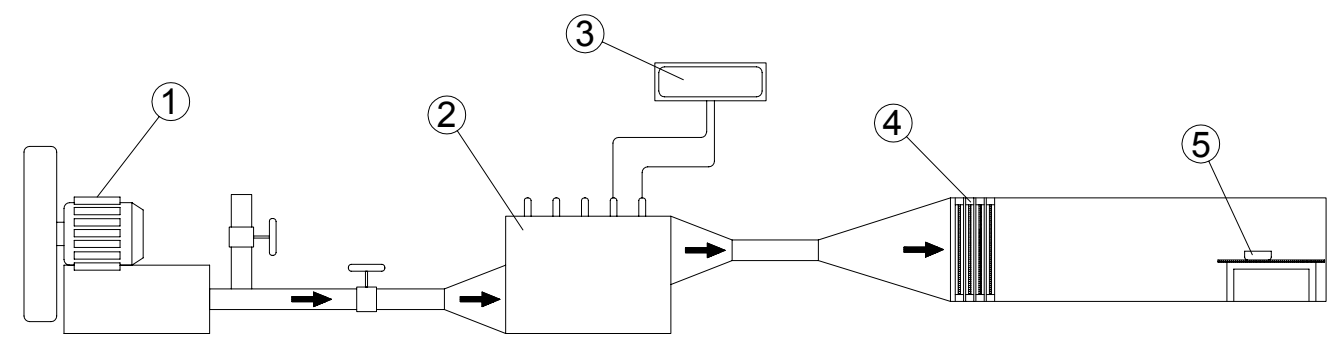

Figure 1: Layout of the experimental unit: (1) blower; (2) heat exchanger; (3) temperature controller; (4) air distribution system; (5) samples. 
Table 2: Drying kinetics equations

\begin{tabular}{|lc|c|l|}
\hline \multicolumn{1}{|c|}{ Equation } & \multicolumn{1}{c|}{ K } & \multicolumn{1}{c|}{ Reference } \\
\hline $\mathrm{MR}=\mathrm{e}^{(-\mathrm{K} \cdot \mathrm{t})}$ & $(2)$ & $\mathrm{K}=\mathrm{A} \cdot \mathrm{e}^{(-\mathrm{B} / \mathrm{T})}$ & Lewis (1921) \\
\hline $\mathrm{MR}=\mathrm{C} \cdot \mathrm{e}^{(-\mathrm{K} . \mathrm{t})}$ & $(3)$ & $\mathrm{K}=\mathrm{A} \cdot \mathrm{e}^{(-\mathrm{B} / \mathrm{T})}$ & Brooker et al. $(1974)$ \\
\hline $\mathrm{MR}=\mathrm{C}\left[\mathrm{e}^{(-\mathrm{K} \cdot \mathrm{t})}+\frac{1}{9} \mathrm{e}^{(-9 \mathrm{~K} \cdot \mathrm{t})}\right]$ & $(4)$ & $\mathrm{K}=\mathrm{A} \cdot \mathrm{e}^{(-\mathrm{B} / \mathrm{T})}$ & Henderson and Henderson (1968) \\
\hline $\mathrm{MR}=\mathrm{e}^{\left(-\mathrm{K} \cdot \mathrm{t}^{\mathrm{d}}\right)}$ & $(5)$ & $\mathrm{K}=\mathrm{A} \cdot \mathrm{e}^{(-\mathrm{B} / \mathrm{T})}$ & Page (1949) \\
\hline $\mathrm{MR}=\mathrm{e}^{-(\mathrm{K} \cdot \mathrm{t})^{\mathrm{d}}}$ & $(6)$ & $\mathrm{K}=\mathrm{e}^{(\mathrm{A}+\mathrm{B} / \mathrm{T})}$ & Overhults et al. (1973) \\
\hline
\end{tabular}

$\mathrm{MR}=\frac{\overline{\mathrm{M}}-\overline{\mathrm{M}_{\mathrm{eq}}}}{\overline{\mathrm{M}_{0}}-\overline{\mathrm{M}_{\mathrm{eq}}}}$

In Equations (2)-(5) the drying constant (K) varies with temperature by a function of the Arrhenius type, however, in the Overhults et al. (1973) equation the function that represents this variation is different, as shown in Table 2.

\section{Rehydration}

The rehydration ratio (RR), given by the ratio of rehydrated sample mass to the dried sample mass, was calculated from the mean value of triplicate measurements. The results were then plotted against time in order to evaluate the rehydration kinetics. The equations used to describe the rehydration kinetics are found in Table 3, where $\mathrm{k}$ is the kinetic constant $\left(\mathrm{min}^{-1}\right), \mathrm{t}$ is the time $(\mathrm{min})$, and $\alpha$ and $\beta$ are parameters of the Weibull equation.

Several rehydration indices were employed to provide information about the influence of absorbed water fluxes and lixiviated solids on the material mass increase. These indices are listed in Table 4. The water absorption capacity of the dried material (WAC) is given in Equation (11). It is the ratio of the mass of absorbed water during rehydration to the mass of water removed during drying, where $m$ is the sample mass, $s$ is the dried solid content $(\mathrm{g} / \mathrm{g}$ on a dry basis), and rh, $\mathrm{d}$ e 0 are subscripts meaning rehydrated, dried and initial sample, respectively.

Table 3: Equations used to describe the kinetics of rehydration

\begin{tabular}{|ll|l|}
\hline \multicolumn{1}{|c|}{ Equation } & \multicolumn{1}{|c|}{ Name } \\
\hline $\mathrm{RR}=\mathrm{RR}_{\mathrm{e}}-\left(\mathrm{RR}_{\mathrm{e}}-1\right) \cdot \mathrm{e}^{-\mathrm{k} \cdot \mathrm{t}}$ & $(8)$ & Exponencial \\
\hline $\mathrm{RR}=\left(\mathrm{RR}_{\mathrm{e}}-1 / \mathrm{k}_{2}\right)+\mathrm{t} /\left(\mathrm{k}_{1}+\mathrm{k}_{2} \cdot \mathrm{t}\right)$ & $(9)$ & Peleg \\
\hline $\mathrm{RR}=\mathrm{RR}_{\mathrm{e}}+\left(1+\mathrm{RR} \mathrm{e}_{\mathrm{e}}\right) \cdot \mathrm{e}^{(-\mathrm{t} / \mathrm{\beta})^{\alpha}}$ & $(10)$ & Weibull \\
\hline
\end{tabular}

$\mathrm{RR}$ : rehydration ratio; $\mathrm{RR}_{\mathrm{e}}$ : saturation rehydration ratio

Table 4: Description of the indices used for rehydration.

\begin{tabular}{|lr|l|}
\hline \multicolumn{1}{|c|}{ Equation } & Description \\
\hline $\mathrm{WAC}=\frac{\mathrm{m}_{\mathrm{rh}}\left(100-\mathrm{s}_{\mathrm{rh}}\right)-\mathrm{m}_{\mathrm{d}}\left(100-\mathrm{s}_{\mathrm{d}}\right)}{\mathrm{m}_{0}\left(100-\mathrm{s}_{0}\right)-\mathrm{m}_{\mathrm{d}}\left(100-\mathrm{s}_{\mathrm{d}}\right)}$ & $(11)$ & water absorption capacity \\
\hline $\mathrm{DHC}=\frac{\mathrm{m}_{\mathrm{rh}} \cdot \mathrm{s}_{\mathrm{rh}}}{\mathrm{m}_{\mathrm{d}} \cdot \mathrm{s}_{\mathrm{d}}}$ & $(12)$ & dry matter holding capacity \\
\hline $\mathrm{RA}=\mathrm{WAC} \cdot \mathrm{DHC}$ & $(13)$ & rehydration ability \\
\hline
\end{tabular}


WAC varies from 0 to 1 and indicates how much the drying reduced the capacity of the product to absorb water. Equation (12) provides information about the capacity of the material to retain soluble solids (DHC), as well as the damage to the tissues and their permeability to solute. This also varies from 0 to 1. Equation (13) evaluates the damages caused by the drying and rehydration processes and the ability of the dried product to rehydrate (RA). Values of RA are in the range of 0 to 1 . The smaller RA the greater is the damage to the vegetable tissue.

\section{Statistical Methodology}

The parameters of the equations for describing drying kinetics (Lewis, 1921; Brooker et al., 1974; Page, 1949; Overhults et al., 1973; Henderson and Henderson, 1968) were estimated by a least squares method, where the data set was all of the experimental observations. To perform all the calculations required to determine the curvature measures (IN and PE), and the bias of Box, a computer program in Fortran language was developed in the present work for the drying kinetics equations.

\section{RESULTS AND DISCUSSION}

The parameters of the equations given in Table 2 were estimated for convective drying. Table 5 shows the results of the least squares (LS) estimation with the respective values for $\mathrm{R}^{2}$ (correlation coefficient), the intrinsic curvature measure (IN), the parametereffects measure (PE) and the bias measures proposed by Box (1971) for all considered equations.

All intrinsic curvature measures (IN), given in Table 5, when compared to the value $1 / 2 \sqrt{\mathrm{F}}$, are not significant for the considered nonlinear models $(\mathrm{IN}<1 / 2 \sqrt{\mathrm{F}})$, which indicates small nonlinearity for the "solution locus" (Ratkowsky, 1983). The parameter effect curvature measures (PE) are significant for the first four equations $(\mathrm{PE}>1 / 2 \sqrt{\mathrm{F}})$, showing that at least one parameter of these equations has a strong nonlinear behaviour. For the Overhults equation, better results are observed, since the curvature measures (PE) are smaller than $1 / 2 \sqrt{\mathrm{F}}$, that is, they are not significant. Thus, for this equation, nonlinearity due to parametrization is small, which implies valid inference results based on asymptotic approximations for the least squares estimators.

Since Equations (2) to (5) present significant nonlinear parameter-effects (PE), the bias measures could show which parameters are responsible for this behaviour ( $\%$ bias $>1 \%)$. An important result is that the nonlinear behaviour (PE) in the first four equations is always associated with the parameter $\mathrm{A}$ (the pre-exponential factor of the Arrhenius equation). The results of Bates and Watts (1980) curvature measures and bias measures (Box, 1971) show that the only equation which gives good inference results, based on least squares estimators, is the Overhults equation.

Table 5: Regression, curvature and bias results

\begin{tabular}{|c|c|c|c|c|c|}
\hline Equation & $\mathbf{R}^{2}$ and $F$ Ratio & Curvature & Parameter & Estimated Value & $\%$ Bias \\
\hline $\begin{array}{l}\text { Lewis } \\
\text { Eq.(2) }\end{array}$ & $\mathrm{R}^{2}=0.99$ & $\begin{array}{l}\mathrm{IN}=0.016 \\
\mathrm{PE}=2.929\end{array}$ & $\begin{array}{l}\mathrm{A} \\
\mathrm{B}\end{array}$ & $\begin{array}{r}32859.61 \\
4762.57\end{array}$ & $\begin{array}{r}8.04 \\
0.004\end{array}$ \\
\hline $\begin{array}{l}\text { Brooker } \\
\text { Eq. }(3)^{* *}\end{array}$ & $\mathrm{R}^{2}=0.99$ & $\begin{array}{r}\mathrm{IN}=0.026 \\
\mathrm{PE}=25.944\end{array}$ & $\begin{array}{l}\mathrm{A} \\
\mathrm{B} \\
\mathrm{C}\end{array}$ & $\begin{array}{r}34200.62 \\
4785.00 \\
0.98 \\
\end{array}$ & $\begin{array}{r}6.88 \\
0.004 \\
0.003 \\
\end{array}$ \\
\hline $\begin{array}{l}\text { Henderson } \\
\text { Eq. (4)** }\end{array}$ & $\mathrm{R}^{2}=0.99$ & $\begin{array}{r}\mathrm{IN}=0.025 \\
\mathrm{PE}=28.169\end{array}$ & $\begin{array}{l}\mathrm{A} \\
\mathrm{B} \\
\mathrm{C}\end{array}$ & $\begin{array}{r}36550.68 \\
4829.69 \\
0.92 \\
\end{array}$ & $\begin{array}{r}8.13 \\
0.004 \\
0.001 \\
\end{array}$ \\
\hline $\begin{array}{l}\text { Page } \\
\text { Eq. }(5)^{* *}\end{array}$ & $\mathrm{R}^{2}=0.99$ & $\begin{array}{r}\mathrm{IN}=0.029 \\
\mathrm{PE}=28.017\end{array}$ & $\begin{array}{l}\text { A } \\
B \\
d\end{array}$ & $\begin{array}{r}22817.00 \\
4582.08 \\
0.96\end{array}$ & $\begin{array}{r}7.46 \\
0.020 \\
0.019 \\
\end{array}$ \\
\hline $\begin{array}{l}\text { Overhults } \\
\text { Eq.(6)** }\end{array}$ & $\mathrm{R}^{2}=0.99$ & $\begin{array}{l}\mathrm{IN}=0.028 \\
\mathrm{PE}=0.029\end{array}$ & $\begin{array}{l}\text { A } \\
B \\
d\end{array}$ & $\begin{array}{r}10.51 \\
-4796.68 \\
0.96\end{array}$ & $\begin{array}{l}0.006 \\
0.004 \\
0.019\end{array}$ \\
\hline
\end{tabular}

$* 1 / 2 \sqrt{\mathrm{F}_{(2 ; 59 ; 0.95)}}=0.281 ; \quad * * 1 / 2 \sqrt{\mathrm{F}_{(3 ; 58 ; 0.95)}}=0.281$ 
Figure 2 shows the results of drying kinetics at 50,60 and $70^{\circ} \mathrm{C}$, for an air flow velocity of $1.5 \mathrm{~m} / \mathrm{s}$, including results fitted by the Overhults equation. The expected significant effect of air temperature on the process can be seen in this figure. The proximity of the predicted results from the Overhults equation to the experimental data can also be verified.

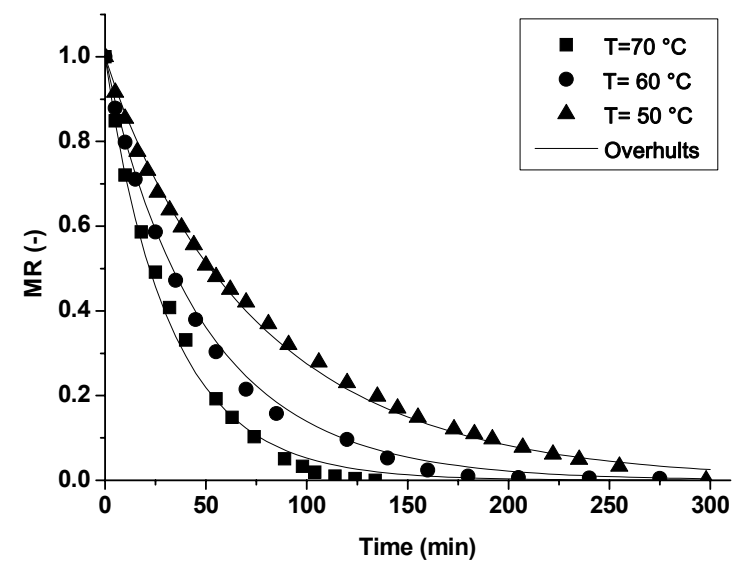

Figure 2: Experimental and fitted results for the drying process.

The same equations were also tested to describe the kinetics of freeze-drying. According to statistical criteria, the Page equation provided the best fit to the data. The values of the parameters of the Page equation are close to some results of the literature for food products, like those found by Marques et al. (2009) for tropical fruits dried by lyophilization, with samples frozen in $\mathrm{N}_{2}(\mathrm{v})$ that obtained a $\mathrm{d}$ value of 1.311. Table 6 shows the parameters values the quadratic coefficient of correlation $\left(\mathrm{R}^{2}\right)$, the sum of squared residuals (SSR) and the mean square error (MSE.).

Table 6: Results of the regression for the kinetics of freeze-drying

\begin{tabular}{|c|c|}
\hline Parameters & Page (1949) \\
\hline K & $2.0 \times 10^{-3} \pm 2.0 \times 10^{-4}$ \\
$\mathbf{d}$ & $1.408 \pm 1.8 \times 10^{-2}$ \\
$\mathbf{R}^{2}$ & 0.999 \\
RSS & $2.0 \times 10^{-5}$ \\
MSE & $5.3 \times 10^{-3}$ \\
\hline
\end{tabular}

The apparent density $\left(\rho_{\mathrm{ap}}\right)$ and the real density $\left(\rho_{\mathrm{r}}\right)$ obtained for the products from convective drying and lyophilization are shown in Table 7. The apparent density $\left(\rho_{\mathrm{ap}}\right)$ of the in natura sample was $969.0 \mathrm{~kg} / \mathrm{m}^{3}$, which is close to the values of some food products in the literature, like pineapple $\left(961.0 \mathrm{~kg} / \mathrm{m}^{3}\right)$, guava $\left(1064.0 \mathrm{~kg} / \mathrm{m}^{3}\right)$ and mango $\left(983.0 \mathrm{~kg} / \mathrm{m}^{3}\right)$ (Marques et al., 2006). The lyophilized sample had a smaller apparent density $\left(120 \mathrm{~kg} / \mathrm{m}^{3}\right)$. In a previous work on lyophilized fruits and vegetables, values of 120.0; $260.0 ; 140.0$ and $180.0 \mathrm{~kg} / \mathrm{m}^{3}$ were found for apple, banana, carrot and potato, respectively (Krokida and Maroulis, 2001).

Table 7: Average values of the apparent density, real densities and porosities from the experiments on convective and freeze drying

\begin{tabular}{|l|c|c|c|}
\hline Drying Process & $\begin{array}{c}\boldsymbol{\rho}_{\mathbf{a p}} \\
\left(\mathbf{k g} / \mathbf{m}^{\mathbf{3}}\right)\end{array}$ & $\begin{array}{c}\boldsymbol{\rho}_{\mathbf{r}} \\
\left(\mathbf{k g} / \mathbf{m}^{\mathbf{3}}\right)\end{array}$ & $\begin{array}{c}\text { Porosity } \\
(\mathbf{\varepsilon})\end{array}$ \\
\hline Convective & 1443 & 2260 & 0.25 \\
Lyophilization & 190 & 2110 & 0.91 \\
\hline
\end{tabular}

The difference in apparent density reflects the effect of the type of drying. Structural changes in the samples occured during convective drying due to the heated air percolation. One example of structural change is cellular collapse, which can lead to an increase in the apparent density of the final product. Shrinkage may also modify the porous distribution inside the material with consequent changes in its apparent density.

Lyophilization produced samples with $\rho_{\mathrm{r}}$ close to those obtained for samples dried with convective drying. Some authors reported that the type of drying process does not have a great impact on the real density of the final product. Krokida and Maroulis (2001), for instance, compared different drying methods and concluded that the only one which had a significant influence on the real density of the final product was osmotic dehydration.

Table 7 also shows values of porosity $(\varepsilon)$ for the pepper dried by the convective and freeze drying processes. The average porosity found for the samples dried by lyophilization (0.91) is close to those usually found in lyophilized fruits (Marques, 2009). The high porosities found for products from lyophilization are a result of the process itself, which employs vacuum and low temperatures. On the other hand, the pores in the convective dried product are mainly related to cellular tensions from high temperatures which end up breaking the food biological structure (Zogzas et al., 1994).

Results of sample shrinkage and moisture content for convective drying at $70{ }^{\circ} \mathrm{C}$ and lyophilization are shown in Figure 3. It is clear from Figure 3 that, as expected, the thickness reduction was approximately proportional to the moisture content decrease.

Madiouli et al. (2007) commented on the fact that the choice of the drying process is significant in terms of final product shrinkage. Krokida and 
Maroulis (1997) showed that convectively dried samples had small porosities and high shrinkage and lyophilized samples had high porosities and small shrinkage.

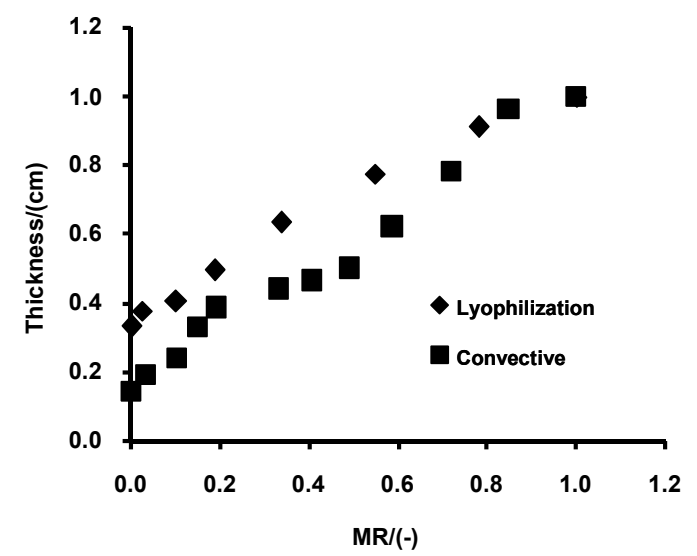

Figure 3: Pepper sample shrinkage as a function of moisture ratio (MR) for convectively dried samples at $70^{\circ} \mathrm{C}$ and freeze-dried samples.

The ascorbic acid (AA-vitamin C) contents of dried samples are listed in Table 8. The ascorbic acid content decreased with increasing air temperature. This may be the result of irreversible oxidation during drying with hot air (Sigge et al., 2001; VegaGálvez et al., 2009). Lyophilized samples had higher levels of vitamin C $(324.5 \pm 8.53 \mathrm{~g} / 100 \mathrm{~g})$. Losses during lyophilization were around $43.7 \%$ with respect to in natura samples. Marques et al. (2009)

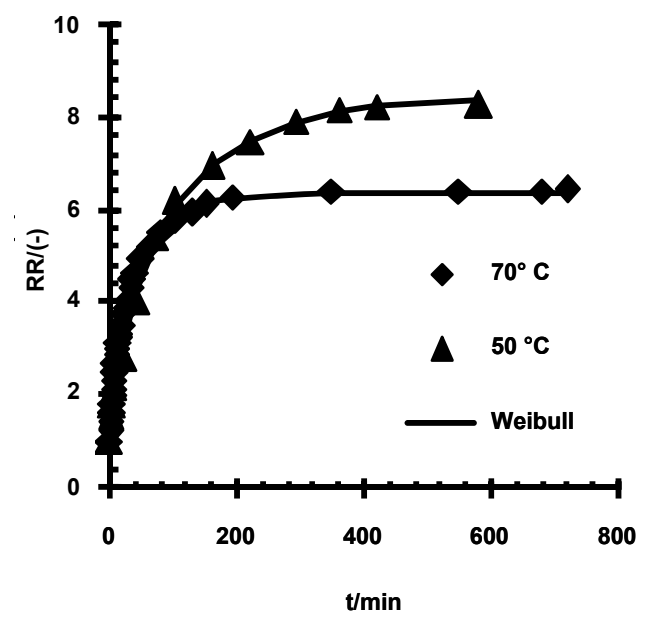

(a) reported that vitamin $\mathrm{C}$ losses of lyophilized guava fruits were up to $37.3 \%$. The low temperatures and residual moisture content levels of lyophilization inhibit the degradation of ascorbic acid.

Table 8: Content of vitamin $\mathrm{C}$ in the dried samples.

\begin{tabular}{|c|c|c|}
\hline $\left.\mathbf{T ~ (} \mathbf{}^{\mathbf{}} \mathbf{C}\right)$ & $\mathbf{m g} / \mathbf{1 0 0} \mathbf{g}$ & Loss (\%) \\
\hline $\mathbf{7 0}$ & $80.5( \pm 34.29)$ & 86.0 \\
$\mathbf{6 0}$ & $113.1( \pm 10.12)$ & 80.0 \\
$\mathbf{5 0}$ & $178.2( \pm 6.57)$ & 69.1 \\
\hline
\end{tabular}

Figure 4 shows results of rehydration kinetics at temperatures of 50 and $70^{\circ} \mathrm{C}$, and a constant air flow velocity of $1.5 \mathrm{~m} \cdot \mathrm{s}^{-1}$. All three plots show a sharp increase of the rehydration ratio (RR) at the beginning of the process. The same behavior was also reported for the rehydration of tropical fruits like pineapple, papaya, mango and acerola (Marques et al., 2009), as well as of carrots (Amami et al., 2007), tomatoes and onions (Krokida and MarinosKouris, 2003). Mass reconstitution of products varied from 83 to $90 \%$ with respect to the mass of the sample before the drying process. The influence of temperature was significant and, as a result, samples dried at $50^{\circ} \mathrm{C}$ absorbed more water than the others in the rehydration process. It seems that this may be due to damages in the material structure and cells caused by the drying process, and to volume shrinkage, which reduces the available intercellular space that is filled with water (Krokida and MarinosKouris, 2003).

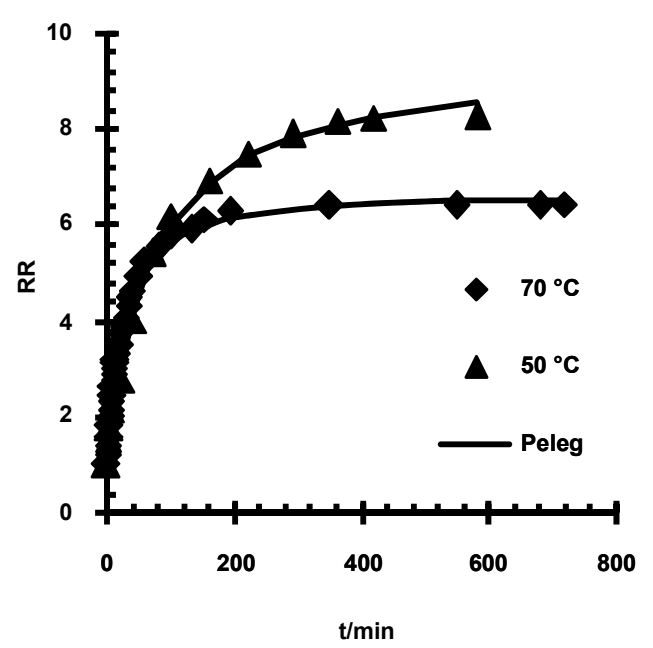

(b) 


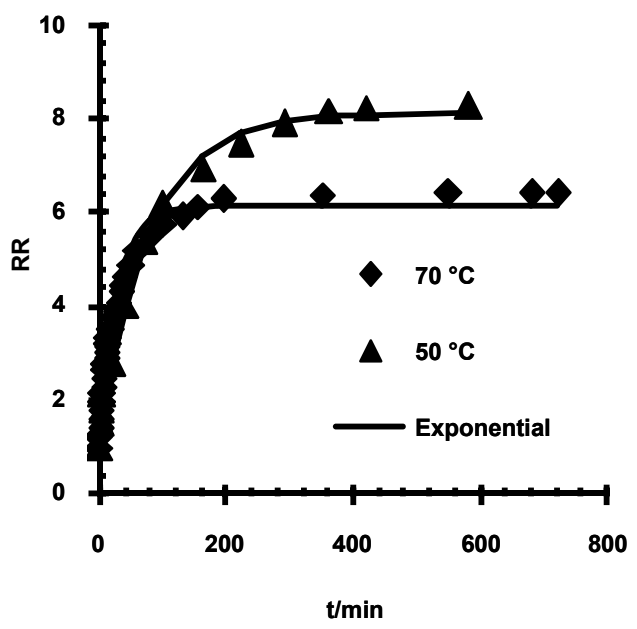

(c)

Figure 4: Rehydration ratio as a function of time for the dried samples with the adjusted Weibull (a), Peleg (b) and Exponential (c) equations.

Table 9 shows the results from the fitting of rehydration kinetic data to the Weibull, Peleg and Exponential equations. The statistical analysis parameters indicate that rehydration kinetics are well described by the three chosen equations, and the fit to the Weibull equation was slightly better. Thus, the Weibull equation was chosen to represent the rehydration kinetics, also because it depends on interesting physical parameters that are meaningful in the rehydration process. It also can be seen in Table 9 that the lowest values of the Weibull parameters ( $\alpha$ and $\beta$ ) were obtained when the samples were dried at the highest temperature $\left(70^{\circ} \mathrm{C}\right)$, indicating that the rehydration rates are smaller when the sample is submitted to drying at higher temperature.

Table 10 presents results of the rehydration indices: capacity of water absorption by the dried material (WAC), capacity of the material to retain soluble solids (DHC) and ability of the dried product to rehydrate (RA). The values of WAC show that more than $80 \%$ of the total amount of water lost during drying was recovered in all cases evaluated. Samples convectively dried at $50^{\circ} \mathrm{C}$ had the highest values of WAC. The highest values of DHC were found for the samples that were submitted to freezedrying. By multiplying WAC and DHC, it is possible to infer information about the coupled effect of the drying and the rehydration processes on product quality. The best results for this coupled effect and for RA were obtained for samples dried by lyophilization. Thus, for this drying process the produced material has a great potential to rehydrate.

Table 9: Estimated parameters and statistical criteria for the Weibull, Peleg and exponential equations at $50{ }^{\circ} \mathrm{C}$ and $70{ }^{\circ} \mathrm{C}$.

\begin{tabular}{|c|c|c|c|c|c|c|c|}
\hline Equation & $\mathbf{T}\left({ }^{\circ} \mathbf{C}\right)$ & $\mathbf{R R}_{\mathrm{e}}(-)$ & $\alpha(-)$ & $\beta$ (min) & $\mathbf{R}^{2}$ & RSS & MSE \\
\hline \multirow{3}{*}{ Weibull } & 50 & 8.461 & 0.786 & 87.850 & 0.997 & 0.025 & 0.157 \\
\hline & 70 & 6.383 & 0.771 & 34.416 & 0.998 & 0.006 & 0.078 \\
\hline & $\mathbf{T}\left({ }^{\circ} \mathbf{C}\right)$ & $\mathbf{R R}_{\mathrm{e}}(-)$ & $\mathbf{k}_{1}(\mathrm{~min})$ & $\mathbf{k}_{2}(-)$ & $\mathbf{R}^{2}$ & RSS & MSE \\
\hline \multirow{3}{*}{ Peleg } & 50 & 9.459 & 8.846 & 0.121 & 0.996 & 0.033 & 0.182 \\
\hline & 70 & 6.726 & 3.871 & 0.173 & 0.998 & 0.005 & 0.071 \\
\hline & $\mathbf{T}\left({ }^{\circ} \mathbf{C}\right)$ & $\mathbf{R R}_{\mathrm{e}}(-)$ & \multicolumn{2}{|c|}{$\mathrm{k}_{1}\left(\mathrm{~min}^{-1}\right)$} & $\mathbf{R}^{2}$ & RSS & MSE \\
\hline \multirow{2}{*}{ Exponential } & 50 & 8.128 & \multirow{2}{*}{\multicolumn{2}{|c|}{$\begin{array}{l}0.013 \\
0.035\end{array}$}} & 0.991 & 0.065 & 0.254 \\
\hline & 70 & 6.155 & & & 0.985 & 0.044 & 0.209 \\
\hline
\end{tabular}

Table 10: Rehydration indices for dried pepper.

\begin{tabular}{|l|c|c|c|c|}
\hline Drying Process & T( $\left.{ }^{\circ} \mathbf{C}\right)$ & WAC & DHC & RA \\
\hline \multirow{2}{*}{ Convective } & 50 & 0.920 & 0.371 & 0.356 \\
& 70 & 0.877 & 0.098 & 0.086 \\
\hline \multicolumn{2}{|c|}{ Lyophilization } & 0.825 & 0.625 & 0.516 \\
\hline
\end{tabular}




\section{CONCLUSIONS}

From the discrimination approach based on nonlinearity measures, it was possible to identify that the Overhults equation was the most appropriate to represent drying kinectics, since statistical analysis presented curvature measures which were not significant. Lyophilization produced samples with the smallest apparent density and real densities close to that obtained by convective drying. The porosities found were directly related to water loss. In terms of ascorbic acid content, lyophilized samples were superior to convectively dried ones. Vitamin C degradation increased with temperature in the convective drying. The material dried by lyophilization showed greater potential to rehydrate.

\section{NOMENCLATURE}

$\begin{array}{llr}\mathrm{A}, \mathrm{B}, \mathrm{C}, & \text { parameters of Equations for } & \\ \mathrm{D}, \mathrm{K} & \text { drying kinetics } & \\ \mathrm{M} 0 & \text { initial moisture content } & \mathrm{kg}_{\mathrm{H} 2 \mathrm{O}} / \mathrm{kg}_{\text {dried solid }} \\ \mathrm{M}_{\mathrm{eq}} & \text { equilibrium moisture } & \mathrm{kg}_{\mathrm{H} 2 \mathrm{O}} / \mathrm{kg}_{\text {dried solid }} \\ \mathrm{MR} & \text { dimensionless moisture } & (-) \\ & \text { number } & \\ \mathrm{t} & \text { time } & \mathrm{min} \\ \mathrm{T} & \text { Temperature } & { }^{\circ} \mathrm{C} \\ \mathrm{V} & \text { Superficial air velocity } & \mathrm{m} \cdot \mathrm{s}^{-1} \\ \alpha, \beta, \mathrm{k} 1, & \text { parameters of rehydration } & \\ \mathrm{k} 2 & \text { equations } & (-) \\ \varepsilon & \text { porosity } & \mathrm{kg} / \mathrm{m}^{3} \\ \rho_{\mathrm{ap}} & \text { apparent density } & \mathrm{kg} / \mathrm{m}^{3} \\ \rho_{\mathrm{r}} & \text { real density } & \end{array}$

\section{REFERENCES}

Lisboa, M. H., Vitorino, D. S., Delaiba, W. B., Finzer, J. R. D., Barrozo, M. A. S., A study of particle motion in rotary dryer. Brazilian Journal of Chemical Engineering, No. 24, p. 265 (2007).

Amami, E., Fersi, A., Khezami, L., Vorobiev, E. and Kechaou, N., Centrifugal osmotic dehydration and rehydration of carrot tissue pre-treated by pulsed electric field. Food Science and Technology, No. 40, p. 1156 (2007).

Arnosti Junior, S., Freire, J. T., Sartori, D. J. M. and Barrozo, M. A. S., Equilibrium moisture content of Brachiaria brizantha. Seed Science and Technology, No. 27, p. 273 (1999).

Barrozo, M. A. S., Souza, A. M., Costa, S. M. and Murata, V. V., Simultaneous heat and mass transfer between air and soybean seeds in a concurrent moving bed. International Journal of Food Science and Technology, No. 36, p. 393 (2001).

Barrozo, M. A. S., Henrique, H. M., Sartori, D. J. M. and Freire, J. T., The use of the orthogonal collocation method on the study of the drying kinetics of soybean seeds. Journal of Stored Products Research, No. 42, p. 348 (2006).

Barrozo, M. A. S., Achcar, J. A., Sartori, D. J. M., Freire, J. T., Discrimination of equilibrium moisture equations for soybean using nonlinearity measures. Drying Technology, v. 14, No.7, p. 1779 (1996).

Bates, D. M. and Watts, D. G., Relative curvature measures of nonlinearity. J. R. Statist. Soc., No. 42, p. 1 (1980).

Box, M. J., Bias in nonlinear estimation. J. R. Statist. Soc., No. 33, p. 171 (1971).

Brooker, D. B., Bakker-Arkema, F. W. and Hall, C. W., Drying Cereal Grains. Westport: The Avi Publishing Co. (1974).

Doymaz, I. Drying kinetics of white mulberry. Journal of Food Engineering, No. 61, p. 341 (2004).

Duarte, C. R., Neto, J. L. V., Lisboa, M. H., Santana, R. C., Barrozo, M. A. S., Murata, V. V., Experimental study and simulation of mass distribution of covering layer of soybean seeds coated in a spouted bed. Brazilian Journal of Chemical Engineering, No. 21, p. 59 (2004).

Ergüneş, G. and Tarhan, S., Color retention of red peppers by chemical pretreatments during greenhouse and open sun drying. Journal of Food Engineering, No. 76, 446 (2006).

Gregory, J. F., Food Chemistry. Marcel-Dekker, New York (1996).

Gupta, P., Ahmed, J., Shivhare, U. S. and Raghavan, G. S. V., Drying characteristics of red chili. Drying Technology, No. 20, p. 1975 (2002).

Henderson, J. M. and Henderson, S. M., A computational procedure for deep-bed drying analysis. J. Agric. Eng. Res., No. 13, p. 87 (1968).

Hunziker, A. T., South American Solanaceae: A Sinopic Survey. Universidad Nacional de Cordoba - Trabajos Del Museo Botanico, Cordoba (1979).

Karathanos, V. T, and Belessiotis, V. G., Application of a thin-layer equation to drying data of fresh and semi-dried fruits. Journal of Agricultural Engineering Research, No. 74, p. 355 (1999).

Kaymak-Ertekin, F., Drying and rehydrating kinetics of green and red peppers. Journal of Food Science, No. 67, p. 168 (2002).

Khalloufi, S., Almeida-Rivera, C. and Bongers, P., A theoretical model and its experimental validation to predict the porosity as a function of shrinkage and collapse phenomena during drying. Food Research International, No. 42, p. 1122 (2009). 
Kim, S., Lee, K. W., Park, J., Lee, H. J. and Hwang, I. K., Effect of drying in antioxidant activity and changes of ascorbic acid and colour by different drying and storage in Korean red pepper (Capsicum annuum L.). International Journal of Food Science and Technology, No. 41, p. 90 (2006).

Kooli, S., Fadhel, A., Farhat, A. and Belghith, A., Drying of red pepper in open sun and greenhouse conditions mathematical modeling and experimental validation. Journal of Food Engineering, No. 79, p. 1094 (2007).

Krokida, M. K. and Marinos-Kouris, D., Rehydration kinetics of dehydrated products. Journal of Food Engineering, No. 57, p. 1 (2003).

Krokida, M. K. and Maroulis, Z. B., Effect of drying method on shrinkage and porosity. Drying Technology, No. 15, p. 2441 (1997).

Krokida, M. K. and Maroulis, Z. B., Structural properties of dehydrated products during rehydration. International Journal of Food Science and Technology, No. 36, p. 529 (2001).

Lewis, W. K., The rate of drying of solid materials. Industrial Engineering Chemistry, No. 13, p. 427 (1921).

Lombraña, J. I. and Jzkara, J., Experimental estimation of effective transports coefficients in freeze drying for simulation and optimization purposes. Drying Technology, No. 14, p. 743 (1996).

Madiouli, J., Lecomte, D., Nganya, T., Chavez, S. and Sghaier, J., A method for determination of porosity change from shrinkage curves of deformable materials. Drying Technology, No. 25, p. 621 (2007).

Marques, L. G., Prado, M. M. and Freire, J. T., Rehydration characteristics of freeze-dried tropical fruits. Food Science and Technology, No. 42, p. 1232 (2009).

Marques, L. G., Silveira, A. M. and Freire, J. T. Freeze-drying characteristics of tropical fruits. Drying Technology, No. 24, p. 457 (2006).

Mujumdar, A. S., Handbook of Industrial Drying. Marcel Dekker, New York (1987).

Overhults, D. G., White, G. M., Hamilton, H. E. and Ross, I. J., Drying soybeans with heated air. Trans. of the ASAE, p. 112 (1973).

Page, C., Factors influencing the maximum rate of drying shelled corn in layers. M.Sc. Dissertation. Purdue University, Indiana, USA (1949).

Ratkowsky, D. A., Nonlinear Regression Analysis. Marcel Dekker Inc., New York (1983).

Ribeiro, J. A., Oliveira, D. T., Passos, M. L. and
Barrozo, M. A. S., The use of nonlinearity measures to discriminate the equilibrium moisture equations for Bixa orellana seeds. Journal of Food Engineering, No. 66, p. 63 (2005).

Rietjens, I. M. C. M., Boersma, M. G., Haan, L., Spenkelink, B., Awad, H. M., Cnubben, N. H. P., Zanden, J. J., Woud, H., Alink, G. M. and Koeman, J. H., The pro-oxidant chemistry of the natural antioxidants vitamin $\mathrm{C}$, vitamin $\mathrm{E}$, carotenoids and flavonoids. Enviromental Toxicology Pharmacology, No. 11, p. 321 (2002).

Scala, K. and Crapiste, G., Drying kinetics and quality changes during drying of red pepper. Food Science and Technology, No. 41, p. 789 (2008).

Sigge, G. O., Hansmann, C. F. and Jourbert, E., Effect of storage conditions, packaging material and metabisulfite treatment on the colour of dehydrated green bell peppers (Capsicum annuum L.). Journal of Food Quality, No. 24, p. 205 (2001).

Tunde-Akintunde, T. Y., Afolabi, T. J. and Akintunde, B., Influence of drying methods on drying bellpepper (Capsicum annuum). Journal of Food Engineering, No. 68, p. 439 (2005).

Turhan, M. and Turhan, K. N., Drying kinetics of red bell pepper. Journal of Food Processing and Preservation, No. 21, p. 209 (1997).

Uddin, M. S., Hawlader, M. N. A., Ding, L. and Mujumdar, A. S., Degradation of ascorbic acid in dried guava during storage. Journal Food Engineering, No. 51, p. 21 (2002).

Vega-Gálvez, A., Di Scala, K., Rodríguez, K., Lemus-Mondaca, R., Miranda, M., López, J. and Perez-Won, M., Effect of air-drying temperature on physico-chemical properties, antioxidant capacity, colour and total phenolic content of red pepper (Capsicum annuum, L. var. Hungarian). Food Chemistry, No. 117, p. 647 (2009).

Veja-Gálvez, A., Fito, P., Andrés, A. and Lemus, R., Mathematical modeling of hot-air drying kinetics of red bell pepper (var. Lamuyo). Journal of Food Engineering, No. 79, p. 1460 (2007).

Vieira, L. G. M., Barbosa, E. A., Damasceno, J. J. R., Barrozo, M. A. S., Performance analysis and design of filtering hydrocyclones. Brazilian Journal of Chemical Engineering, No. 22, p. 143 (2005).

Zogzas, N. P., Maroulis, Z. B. and Marinos-Kouris, D., Densities, shrinkage and porosity of some vegetables during air drying. Drying Technology, No. 12, p. 1653 (1994). 